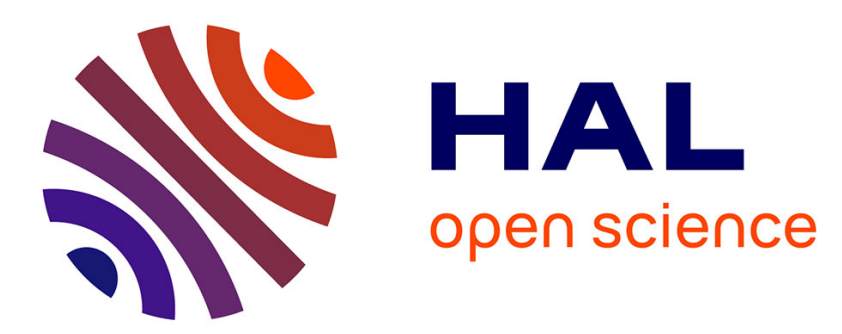

\title{
Statistical distribution of series of 12 monthly concentration samples for environmental classification of rivers
}

J. Eliasson, T. Thordarson

\section{- To cite this version:}

J. Eliasson, T. Thordarson. Statistical distribution of series of 12 monthly concentration samples for environmental classification of rivers. Hydrology and Earth System Sciences Discussions, 2007, 4 (4), pp.2561-2585. hal-00298869

\section{HAL Id: hal-00298869 \\ https://hal.science/hal-00298869}

Submitted on 7 Aug 2007

HAL is a multi-disciplinary open access archive for the deposit and dissemination of scientific research documents, whether they are published or not. The documents may come from teaching and research institutions in France or abroad, or from public or private research centers.
L'archive ouverte pluridisciplinaire $\mathbf{H A L}$, est destinée au dépôt et à la diffusion de documents scientifiques de niveau recherche, publiés ou non, émanant des établissements d'enseignement et de recherche français ou étrangers, des laboratoires publics ou privés. 
Hydrol. Earth Syst. Sci. Discuss., 4, 2561-2585, 2007 www.hydrol-earth-syst-sci-discuss.net/4/2561/2007/

(C) Author(s) 2007. This work is licensed under a Creative Commons License.
Hydrology and Earth System Sciences Discussions

Papers published in Hydrology and Earth System Sciences Discussions are under open-access review for the journal Hydrology and Earth System Sciences

\section{Statistical distribution of series of 12 monthly concentration samples for environmental classification of rivers}

\section{J. Eliasson ${ }^{1}$ and T. Thordarson ${ }^{2}$}

${ }^{1}$ University of Iceland, Institute of Environmental and Civil Engineering, Iceland

${ }^{2}$ University of Iceland, Research Station in Hveragerdi, Iceland

Received: 20 July 2007 - Accepted: 26 July 2007 - Published: 7 August 2007

Correspondence to: J. Eliasson (jonase@ @i.is)

\section{HESSD}

4, 2561-2585, 2007

Statistical distribution of series

J. Eliasson and

T. Thordarson

Title Page

Abstract Introduction

Conclusions References

Tables Figures

14 $>$ I

4

Back

Close 


\section{Abstract}

Environmental monitoring and classification of rivers in the northern hemisphere is frequently hampered by lack of infrastructure in the scarcely populated areas of the north. Carefully designed economical methods are important. Analysis of 15 constituents in

514 rivers in Iceland show that monthly samples for a period of 1 year are sufficient for classification provided that the correct statistical distribution is known. Normalizing and plotting all the constituents in each river by rank shows systematic deviations from both the normal and lognormal distributions. When the constituents are pooled by river the result is one distribution for each river, all very similar. A new cumulative distribution

function $(\mathrm{DoC})$ is formed as the average of these. It has a long tail similar to that of the lognormal distribution but below the $60 \%$ quantile, the DoC differs a lot from the lognormal so if it is to be used, an unbiased estimate of the scale and location parameters will in most cases be difficult to obtain if more than $30-40 \%$ of the highest points is used. The influence of the $\mathrm{DoC}$ on the classification result is very strong when the $1590 \%$ quantile is used for classification, but fades out at the $60 \%$ quantile. It is shown that the storage effect in rivers with a lake that holds some weeks flow in storage, can have a great influence on the classification result.

\section{Introduction}

In Europe the classification systems for the degree of anthropogenic impact on surface water is based on ecological status involving both the biology and the chemistry of the rivers as set forth in the European Union Water Framework Directive (WFD, EU 2000/60/EC).

The climate in Iceland is cold oceanic with cool summers and relatively warm winters. The mean temperature (1961-1990) of the coldest (January) and warmest (July) month mean annual temperature in North-Iceland (Akureyri) is $3.2^{\circ} \mathrm{C}$ and the mean annual
HESSD

4, 2561-2585, 2007

\section{Statistical \\ distribution of series}

J. Eliasson and

T. Thordarson

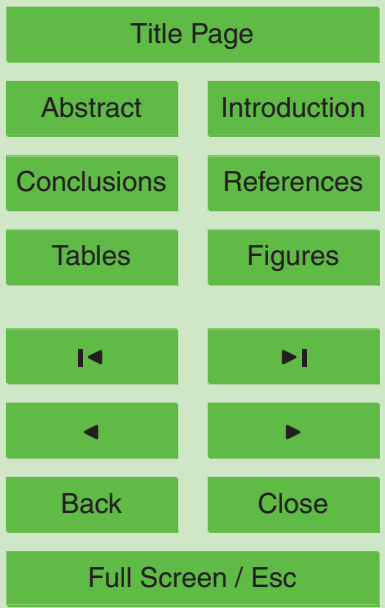

Printer-friendly Version

Interactive Discussion 
precipitation $490 \mathrm{~mm}$. For Southwest Iceland (Reykjavik) these values are $4.3^{\circ} \mathrm{C}$ and $799 \mathrm{~mm}$. This data and further information may be compiled from the official website of the Icelandic Meteorological Office: http://andvari.vedur.is/english/.

Iceland is mostly made up of Quaternary and Tertiary igneous basaltic rock that 5 strongly influences the chemistry of rivers (Stefansson, 2001). Owing to continental drift the youngest rock is in a rift zone which for the most part extends southwest from the northeastern part of Iceland, over the central highlands to the Reykjanes peninsula (Fig. 1). The rift zone is volcanically active and in areas with postglacial lava fields surface water is uncommon owing to high permeability of the bedrock, maybe as high 10 as $1-10^{-2} \mathrm{~m} / \mathrm{s}$ (Eliasson, 1994). Rivers in the outskirts of the Quaternary rock formatins are often spring fed and their water very pure (Sigurðsson and Ingimarsson, 1990) but the clastic sediments and hyaloclasites in this zone sometimes have $10^{-3}-10^{-6} \mathrm{~m} / \mathrm{s}$, which is enough to hold surface streams (Eliasson, 1994).

The concentration of natural dissolved solids is relatively stable in spring fed rivers 15

but fluctuates in glacial and direct run-off rivers which also have higher concentration and lower discharge in winter time. The rivers acquire their natural solutes mostly from precipitation or from leaching from rocks but many rivers in Iceland receive runoff from geothermal aquifers where the concentration is very dependent on temperature. An excellent review of surface water chemistry in Iceland is given in (Stefansson, 2001)

and (Stefansson et al., 2001). Generally the concentration of chemical constituents is lower in Icelandic rivers than the world average with the exception of silica (Si), sodium $(\mathrm{Na})$, ammonium $\left(\mathrm{NH}_{4}\right)$ and phosphorus $(\mathrm{P})$ (Stefansson et al., 2001).

Only $23805 \mathrm{~km}^{2}$ of Iceleand is covered with vegetation (Statistics_Iceland, 2007), mostly the lowlands. The uppermost reaches of most of the rivers studied are in areas with only thin and patchy vegetative cover.

Agriculture is considered to be the most common source of anthropogenic pressure on surface water in Iceland followed by rural settlements and summer cabins that are for the most part sparsely populated. Urbanized areas are usually a relatively small part of drainage areas in Iceland. Both agriculture and urbanized areas are situated
HESSD

4, 2561-2585, 2007

\section{Statistical distribution of series}

J. Eliasson and

T. Thordarson

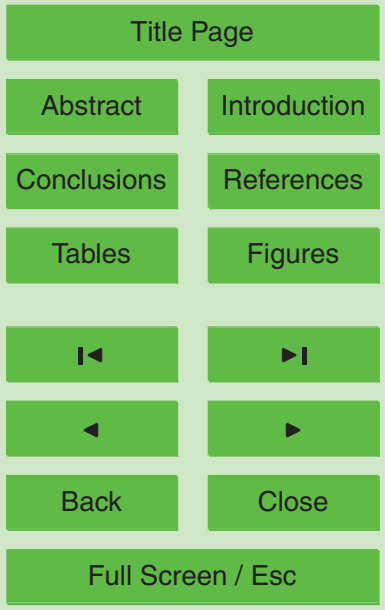

Printer-friendly Version

Interactive Discussion 
in the lower reaches of the drainage areas. The upper reaches of the drainage areas are generally governed by pristine conditions but used as pasture for sheep in the summertime.

The data in this paper was collected in order to classify the rivers according to water 5 quality and degree of human impact, the basis for the pollution classification of rivers in Iceland, set forth in Regulation 796/1999, will be investigatied and the methods used evaluated. Water quality monitoring, compatible with the requirements of the EU WFD, is a problem in a country like Iceland because of the large number of streams and the small population. This is a problem common for the northern regions of Europe. 10 Consequently an economical classification method is important. In the following we describe a classification method designed to meet the requirements of the ruling of the government of Iceland and possible modifications are discussed.

\section{Study area and sampling sites}

The sampling sites were chosen near the estuaries of the rivers at a place of easy 15 access. The rivers in this study are all in the Southwest and the Northeast regions of Iceland, they are listed and numbered in Table 1. Seven rivers in southwest Iceland and seven in south Iceland were sampled on a monthly basis 12-14 times. In both regions the rivers are located either in the active rift zone or outside it. The combined drainage area of the studied rivers in southwest Iceland is $1310 \mathrm{~km}^{2}$ but $9877 \mathrm{~km}^{2}$ 20 $11 \%$ of the total surface area of Iceland. The elevation of the discharge areas extended
from near sea level to approximately $900 \mathrm{~m}$ over sea level in southwest Iceland and to approximately $2000 \mathrm{~m}$ over sea levels in north Iceland.

To achieve an economical method sampling frequency has to be suitably low. Nor25 wegian rules (Norsk_Institutt_for_vannforskning, 1997) state that 1 monthly sample is minimum for big rivers, but twice a year for small rivers in pristine conditions. In this investigation it was decided to use the monthly sampling frequency until some experi-
HESSD

4, 2561-2585, 2007

\section{Statistical \\ distribution of series}

J. Eliasson and

T. Thordarson

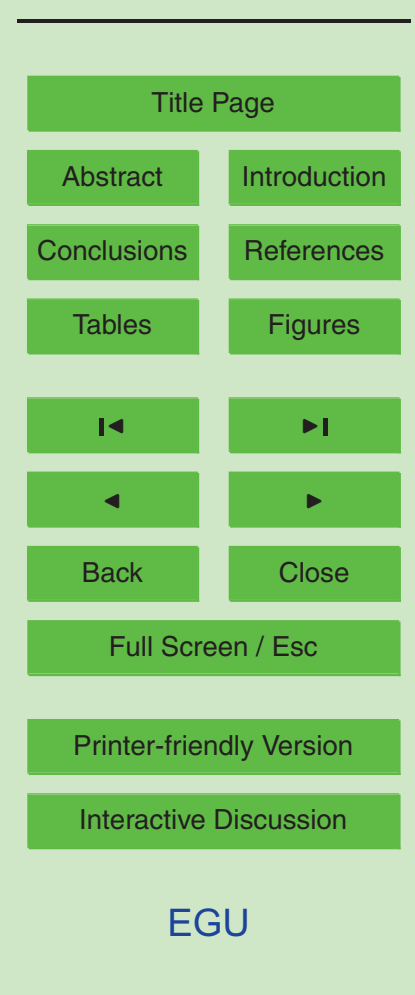




\section{Statistical investigation}

\subsection{Objectives}

The main objective of the statistical investigation is to find the distribution of the con5 information we get about the average properties in Table 1, and use them in classification. In order to do so, all the constituents were normalized by subtracting the 12 months average and dividing by the standard deviation (Eliasson, 1997). By this we create a statistic with zero mean and standard deviation equal to one, for all the constituents in each river. Now there is one number for each month and each constituent in every river. The months can be ranked and the distributions can be plotted and compared. If the constituents have a common two-parameter distribution it will conveniently show in graphical display.

\subsection{Normal distribution}

15 Using the fact that the constituents do not have a strong seasonal correlation they can be compared to the normal, or Gaussian, distribution. There are only 12 numbers for each constituent in each river so the distributions plots as in Fig. 2. It shows the constituents from a river Laxa in Thingeyjasysla, no. 3 in Table 1. The river originates from the spring fed lake Myvatn, which is an eutrophic lake with high production, rich

\section{Fig. 3.}

Figure 2 is so produced that a smoothed line is drawn through all 12 values of the ranked constituents so the distribution they indicate can be compared to a red line of the normal probabilities of the same rank. The selected smoothing method exaggerates the differences between the ranks but at the same time makes it easier to identify the
4, 2561-2585, 2007

\section{Statistical \\ distribution of series}

J. Eliasson and

T. Thordarson

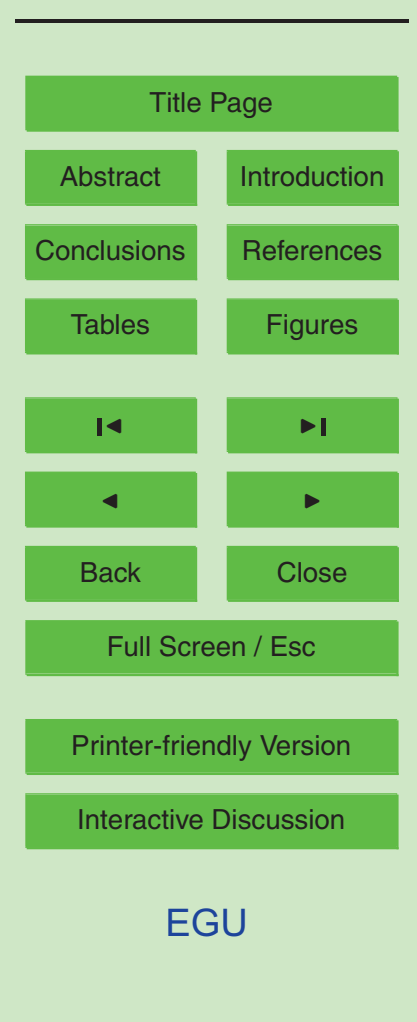


actual line and follow it through all 12 ranks. Three reasons that cause the distributions to deviate from the red line for normality can be identified. Practically all rank 1 values are above the red line, most rank 4-10 values are below it and rank 11 and 12 points are above it. This is a sysematic error which can be seen on Fig. 3 for 8 more rivers, 5 but statistical tests do not reject the normal distribution for most of these series. The six rivers not plotted in Fig. 3 contain no new information.

Practically the same features as above cause the logarithms of the values for the concentrations of the constituents to deviate from the normal distribution for all the streams and rivers as can be seen in the example in Fig. 4. All values on the vertical 10 axis are in log space.

The lognormal distribution is very popular in environmental studies and many times used without any dicussion about its applicability. This is not unjustified when extreme values are concerned as will be demonstrated later.

\subsection{Non-parametric approach}

15 The constituents show a clear deviation from the normal and lognormal distributions, but the deviation is not the same from river to river. Take as an example the TC line for no. 13 Fossá. It shows high values in the high and low ranks, but is relatively flat in between. In the absence of more information an observational error in the high and low values would be suspected. But because the other rivers show similar high rank and 20 low rank values without the flat middle we know that this is not necessarily the case. Besides, the TC line is the sum of the TOC and IC lines and they do not behave in this manner as can e.g. be seen in Fig. 2.

The bold lines in Fig. 5 show the variations of the normalized data when the fourth highest (high), the median (med) and the fourth lowest (low) of all constituents of same 25 rank in a river are plotted. The bold lines thus show the $21 \%, 50 \%$ and $79 \%$ average quantiles of constituents of all 14 rivers and also the standard deviations, all 14 rivers considered. This is used to produce the lines marked plus and minus which indicate one standard deviation around the respective quantile. According to the central limit
HESSD

4, 2561-2585, 2007

\section{Statistical \\ distribution of series}

J. Eliasson and

T. Thordarson

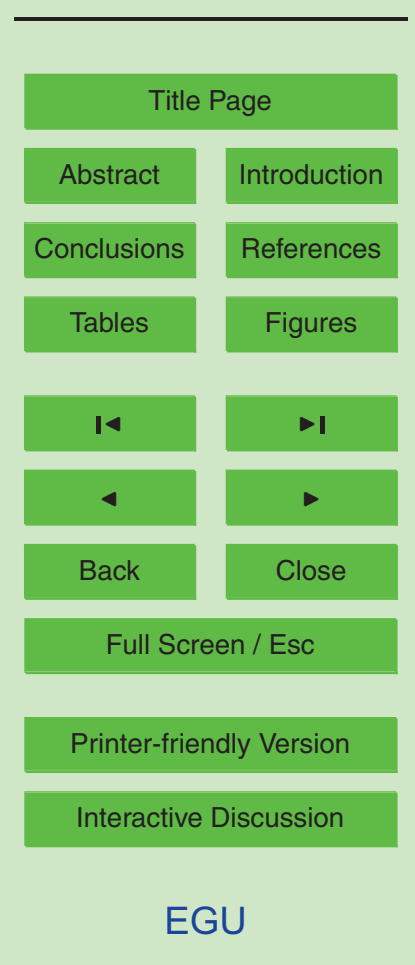


theorem the distribution around the bold lines in Fig. 5 should be close to the normal distribution, as each value on that line is an average for 14 rivers. Then $68 \%$ of the probability mass should be within the slim lines of same color around the bold high, med and low lines. All the data can be plotted as points on Fig. 5 and $78 \%$ of the 5 points would fall within the bold lines. Figure 5 thus shows that the variance between constituents (the difference between the bold lines) and the variation between rivers (difference between the slim lines and the same color bold line) is small compared to the variation within the constituents themselves (note the difference between ranks on the vertical scale). Having only 12 points for each river in each year, this strongly 10 indicates, that the best thing to do, is to use the same distribution for all the constituents and all rivers, and in this case it is not the lognormal distribution as widely suggested (see discussion later).

\subsection{The constituent distribution}

If a two-parameter distribution function exists for the constituents in each river, we can 15 now find it by pooling the results behind Fig. 5 by river (Eliasson, 1997). The result is on Fig. 6. It shows the empirical distribution of each river found by pooling 11 constituents. Of the original 15 the following are not included: $\mathrm{pH}$, Conductivity and Fecal coliforms due to significant correlation to air temperature in some rivers, and TC as it is a sum of two other parameters. However, it does not make any significant change to exclude 20 them. The resulting distributions for the rivers are very much alike so DoC (Distribution of Constituents) is now found as the average of all rivers (bold red line).

\subsection{The probability density function of DoC}

Discrepancies in empirical distribution functions do show better in probability density functions than in cumulative distribution functions. The DoC probability density function 25 is shown in Fig. 7.

Figure 7 shows that even though the DoC looks nice on Fig. 6 it is by no means

\section{HESSD}

4, 2561-2585, 2007

\section{Statistical \\ distribution of series}

J. Eliasson and

T. Thordarson

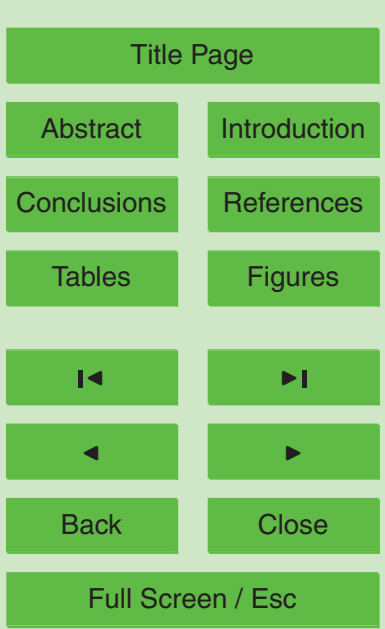

Printer-friendly Version

Interactive Discussion 
flawless. It is compared to the lognormal distribution we would get by sliding the distribution on the horizontal axis 2.3 to the right, probability densities calculated and slid back. This is necessary in order to avoid negative values and must be done as negative concentrations do not occur in practice.

$5 \quad 3.6$ The probability factor of the DoC

The DoC is a cumulative probability distribution function, $\Phi_{\text {DoC }}$, stating:

$P\left(\frac{X-\bar{X}}{s_{X}}<x\right)=\Phi_{\mathrm{DoC}}(x)$

or

$\frac{X-\bar{X}}{s_{X}}=P^{-1}\left(\Phi_{\mathrm{DoC}}(x)\right)=>X=\bar{X}+K s_{X}$

$10 P=$ probability

$K=$ probability factor defined in Eq. (2)

$s_{X}=$ standard deviation

$X=$ observation value

$\bar{X}=$ average value

$15 K$ can be taken from Table 2, compiled from the data behind Fig. 6

\section{Concentration classes using the DoC}

\subsection{Concentration limits}

Having established the parameters of the distribution to be expected (Table 2) it is possible to classify the rivers in Table 1 according to the ruling of Regulation no. 796/1999

\section{HESSD}

4, 2561-2585, 2007

\section{Statistical}

distribution of series

J. Eliasson and

T. Thordarson

Title Page

Abstract

Introduction

Conclusions

References

Tables

Figures

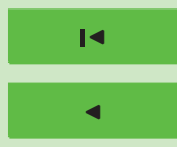

Back

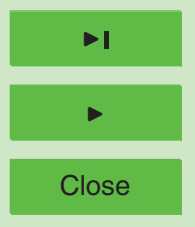

Full Screen / Esc

Printer-friendly Version

Interactive Discussion 
(The_Environment_and_Food_Agency_of_Iceland, 1999). In this regulation a 90\% concentration class limit is prescribed, so the $90 \% \mathrm{~K}$ in Table 2 . has to be used.

HESSD

$X(90 \%)=\bar{X}+1.48 s_{X}=\bar{X}\left(1+1.48 C_{V}\right)$

The coefficient of variation $C_{v}$, is to be taken from Table 1 or a similar source.

5

Similarly, if a mean value is to be within its class on the $90 \%$ safety level, still taking only one measurement in each month, Eq. (1) must be inverted.

$\bar{X} \leq X(90 \%) /\left(1+1.48 C_{V}\right)$

This would be the wanted mean value to keep in order to ensure that $90 \%$ of the observations will be within the class limits when $X(90 \%)$ is the higher limit for the class.

A different interpretation of Regulation no. $796 / 1999$ is possible. That is to say that for monthly observations one year is not enough basis for classification. This is a view shared by many researchers studying censored data (Johnes et al., 1996) and (Johnes, 2007) recommends daily samples, (Guo et al., 2002) investigate nitrate-N load estimates when monitoring durations were 1,2, 3, and 6 years, and the sam15 pling frequencies ranged from weekly to bimonthly. They base their estimates on rating curve, ratio estimator and flow-weighted average estimator for each sampling scenario, and then use two bias correction techniques, minimum variance unbiased estimator (MVUE) and smearing estimator. They state that a desired accuracy of the estimates could be achieved either by sampling more frequently or by monitoring the site longer. This result then means that a monthly sampling frequency can be made accurate enough by using an observation period long enough, but does not really say that one year is sufficient. It is thus possible to increase the classification accuracy of monthly samples by measuring more than one year. If the average concentration of each year in now called one observation, the $90 \%$ ruling can be used on these. Doing

so, two facts have to be remembered. First, instead of the $C_{v}$ value in Table 1, a new coefficient of variation with the expected value $C_{v}^{*}=C_{v} / \sqrt{ } 12$ emerges. Secondly the DoC will not be valid any more, if we add up a distribution 12 times, the central limit
4, 2561-2585, 2007

\section{Statistical \\ distribution of series}

J. Eliasson and

T. Thordarson

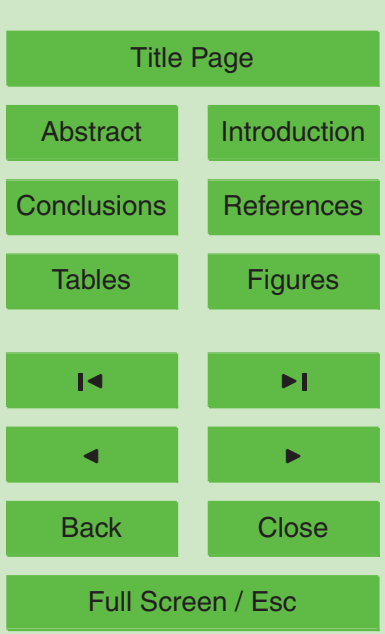

Printer-friendly Version

Interactive Discussion 
theorem will have turned up the Normal (Gaussian) distribution, irrespective of what the mother distribution is. Now the formula changes to,

$\bar{X}=X(90 \%) /\left(1+1.16 C_{V}^{*}\right)$

Equation (5) produces a considerably higher value than Eq. (4) if the same $X(90)$ is 5 used.

\subsection{Using the $90 \%$ rule or averages for the class definition}

As the Figs. 2-6 clearly show, statistical significance of the $90 \%$ limit is very low. In Fig. 2, 90\% correspond to the rank 2 value, this fluctuates from 0,5 to more than 2 , or over 1.5 standard deviations. Around the mean value there is much greater stability, so if we base the classification on 12 monthly values only, to make use of the mean value and the DoC to estimate the $90 \%$ value, is a better choice than using the rank 2 values. In this way Table 1 can easily be turned into a class determining table by using Eq. (1) to calculate the $90 \%$ values that must not be exceeded in a series of 12 monthly values and compare them to the class limits. All together there are five classes, and the classes for each constituent in the 14 rivers is shown under the $90 \%$ heading in Table 3.

In Table 3 under the $60 \%$ heading we also see, the resulting classes if the rivers are classified according to mean value. $C_{\max }$ is the highest class, signifying that the environmental state of the river as a whole is this class or better, all constituents considered. In Table 3 there are also the classes that would result from a $60 \%$ rule or classification by average.

\section{A note on the current practice of classification}

As mentioned above reg. 796/199 stipulates that the environmental classification of surface waters is to be done at the $90 \%$ significance level. Due to lack of data, the
HESSD

4, 2561-2585, 2007

\section{Statistical}

distribution of series

J. Eliasson and

T. Thordarson

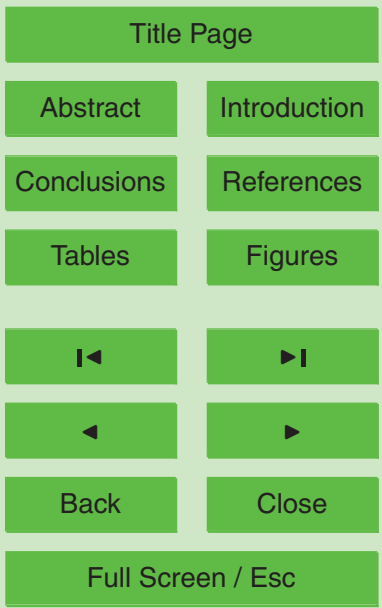

Printer-friendly Version

Interactive Discussion 
rivers classified so far in Iceland have been classified based on average values from 10-14 samples over approximately one year, in order to achieve realistic classification within manageable financial restrains, this corresponds to the $60 \%$ significance level according to the DoC. In order to achieve the $90 \%$ confidence interval using only the 5 mean or the geometric mean, and not having established the validity of the DoC, a much larger number of samples would be needed. This is discussed in more detail later.

\section{Discussion}

The DoC gives the best fit to the data, it can be used in monitoring involving monthly 10 samples, but the studied data is to small to recommend it to be used for other data sets. It is still a question when the DoC has to be used or if the $\log N$ may be used instead, Fig. 7 shows that the high tail of DoC follows the $\log N$ tail very closely, so investigators only concerned about the high values can use logN and achieve the same result. The problem is the estimation of the scale parameter and the location parameter, whose estimates will be biased because how the DoC deviates from the lognormal everywhere below the average. In this range the probability weights of the lognormal differ from the DoC by a factor of 2 to either side. This may be helped by taking the parameters from the tail where the distributions are almost identical and get an unbiased estimate that way. E.g. the significant value (average of the highest third of the data) may be used.

Other parameters produced by maximum likelihood estimates using only the highest one third of the data may also be used.

This long tail produces many problems in classification. The most outstanding is the significance of the storage effect. When a river runs through a lake containing a few weeks run-off in storage then the concentrations in the outflow vary much less than in the inflow. This may be seen in Table 3. Elliðaa (No. 4) is the outflowing river from a lake, Elliðavatn, that is a hydropower storage reservoir. Elliðaa is classified in a better class than the inflowing rivers, Holmsa and Sudura when the $90 \%$ rule is used.
HESSD

4, 2561-2585, 2007

\section{Statistical \\ distribution of series}

J. Eliasson and

T. Thordarson

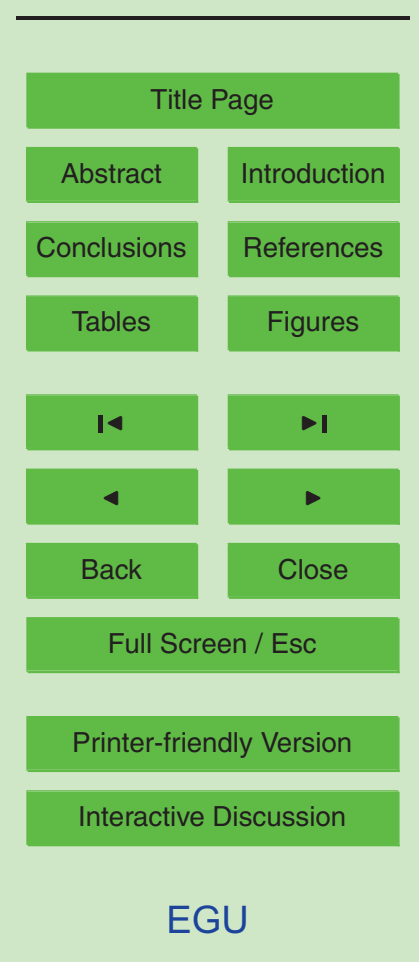


Changing to a $60 \%$ rule makes inflow and outflow classes equal. This difference is caused by the heavy weight of the term 1,48 $C_{V}$ in Eqs. (1) and (2) and the fact that the $C_{v}$ values are greater for the inflowing rivers because of the storage effect.

HESSD

4, 2561-2585, 2007

\section{Conclusions}

5 The normalized concentrations of the constituents in each river investigated define a distribution function when pooled together. It can be any distribution, not necessarily the lognormal. The pooling presumes that the constituents do belong to a common twoparameter distribution, a presumption already in use in most environmental monitoring practice.

10 Averaging the distributions of 14 rivers produces the DoC with surprising accuracy as the 14 distributions are very similar, using the $\mathrm{DoC}$ is within 0.2 everywhere in Fig. 6 , so class determination will be within $0.2 \sigma$.

When high concentration values are the only concern, the lognormal distribution produces the same result as the DoC. But parameters have to be estimated with unbiased 15 estimates using $40 \%$, or less, of the highest values.

$C_{v}$ 's can be rather high so the $90 \%$ rule of the Regulation no. $796-1999$ can create a large fluctuation in class determination due to high influence of the $C_{v}$ and the unavoidable fluctuations of this parameter when classification is based on only 12 monthly samples. This classification problem can be circumvented by using $C_{V}$ values averaged over 6-12 years and Eq. (3), thus avoiding the influence of the long tail of the DoC.

Variance reducing storage effects can lead to the unexpected result that rivers in pristine condition can fall in a worse class than the same river in lowland areas under higher environmental pressure. Classification according to $60 \%$ rule instead of $90 \%$ avoids this flaw.

\section{Statistical}

\section{distribution of series}

J. Eliasson and

T. Thordarson

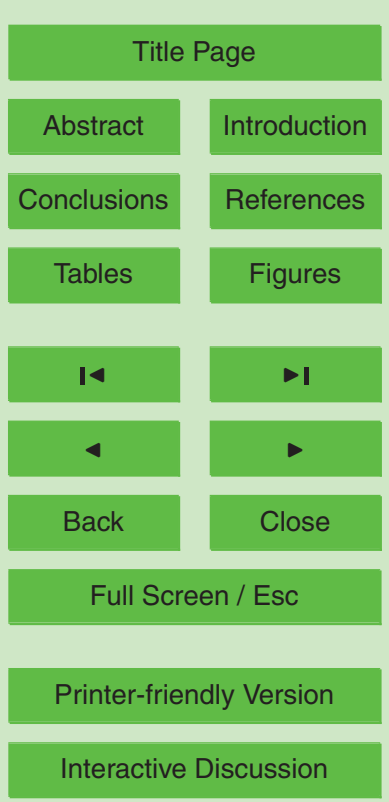




\section{References}

Eliasson, J.: Northern Hydrology in Iceland, (in Northern Hydrology International Perspectives, edited by: Prowse, T. D., Omanney, C. S. L., and Watson, L. E.), NHRI Science Report No. 3, 41-79, Fig. 4.9, 1994.

5 Eliasson, J.: A statistical model for extreme precipitation, Water Resour. Res., 33(3), 449-455, 1997.

Guo, Y., Markus, M., and Demissie, M.: Uncertainty of nitrate-N load computations for agricultural watersheds, Water Resour. Res., 38(10), 1185-1199, 2002.

ISO: ISO 9308-1:2000 Water quality - Detection and enumeration of Escherichia coli and coliform bacteria - Part 1: Membrane filtration method, 2000.

Johnes, P., Moss, B., and Phillips, G.: The determination of total nitrogen and total phosphorus concentrations in freshwaters from land use, stock headage and population data: Testing of a model for use in conservation and water quality management, Freshwater Biol., 36(2), 451-473, 1996.

15 Johnes, P. J.: Uncertainties in annual riverine phosphorus load estimation: Impact of load estimation methodology, sampling frequency, baseflow index and catchment population density, J. Hydrol., 332(1-2), 241-258, 2007.

Norsk_Institutt_for_vannforskning: Classification of Environmental Quality in freshwater (Klassifikering av miljökvalitet i ferskvann; in Norwegian), Veiledning 97:04, 1997.

Sigurðsson, F. and Ingimarsson, J.: Lekt íslenskra jarðefna, in: Vatnið og landið, edited by: Sigbjarnarson, G., Orkustofnun, Reykjavík, 121-128, 1990.

State of New York Department of Health: Environmental laboratory approval program certification manual, Item no. 198.3, Procedural Modification for Drinking Water Total Coliform, 3 pp., 2005.

Statistics_Iceland: Geography and environment, http://www.statice.is/, 2007.

Stefansson, A.: Dissolution of primary minerals of basalt in natural waters - I. Calculation of mineral solubilities from 0 degrees C to 350 degrees C, Chem. Geol., 172(3-4), 225-250, 2001.

Stefansson, A., Gislason, S. R., and Arnorsson, S.: Dissolution of primary minerals in natural waters - II. Mineral saturation state, Chem. Geol., 172(3-4), 251-276, 2001.
HESSD

4, 2561-2585, 2007

Statistical

distribution of series

J. Eliasson and

T. Thordarson

Title Page

Abstract

Introduction

Conclusions

References

Tables

Figures

14

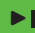

4

Back

Close

Full Screen / Esc

Printer-friendly Version

Interactive Discussion 
The_Environment_and_Food_Agency_of_Iceland:

http://www.reglugerd.is/interpro/dkm/WebGuard.nsf/b7fd33650490f8cf00256a07003476bb/ 8740f17f27ea86cd00256a0800330269?OpenDocument (in Icelandic), 1999.

\section{HESSD}

4, 2561-2585, 2007

\section{Statistical}

\section{distribution of series}

J. Eliasson and

T. Thordarson

Title Page

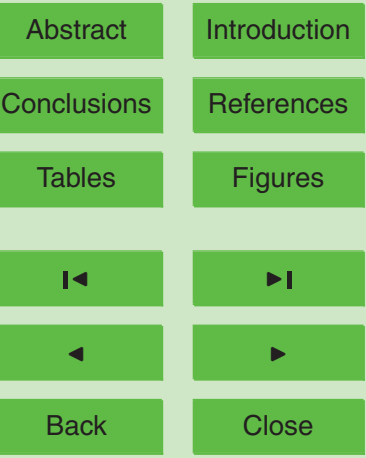

Full Screen / Esc

Printer-friendly Version

Interactive Discussion 
Table 1. Average physiochemical properties of the rivers studied (Ave), coefficient of variation $\left(C_{\mathrm{var}}\right)$ and correlation coefficient $(r)$.

\begin{tabular}{|c|c|c|c|c|c|c|c|c|c|c|c|c|c|c|c|c|c|c|c|}
\hline & No & & $\begin{array}{l}\text { Air temp } \\
{ }^{\circ} \mathrm{C}\end{array}$ & $\begin{array}{l}\text { Water temp } \\
{ }^{\circ} \mathrm{C}\end{array}$ & $\mathrm{pH}$ & $\begin{array}{c}\text { Conductivity } \\
\text { uS/cm }\end{array}$ & $\begin{array}{c}\text { Fec. colif. } \\
100 \mathrm{ml}\end{array}$ & $\begin{array}{c}\mathrm{t}-\mathrm{P} \\
(\mathrm{mg} / \mathrm{l})\end{array}$ & $\begin{array}{l}\mathrm{PO}_{4}-\mathrm{P} \\
(\mathrm{mg} / \mathrm{ll})\end{array}$ & $\begin{array}{l}\mathrm{t}-\mathrm{N} \\
(\mathrm{mg} / \mathrm{l})\end{array}$ & $\begin{array}{l}\mathrm{NH}_{4}-\mathrm{N} \\
(\mathrm{mg} / \mathrm{l})\end{array}$ & $\begin{array}{l}\text { TOC } \\
(\mathrm{mg} / \mathrm{l})\end{array}$ & $\begin{array}{c}\mathrm{IC} \\
(\mathrm{mg} / \mathrm{l})\end{array}$ & $\begin{array}{c}\mathrm{TC} \\
(\mathrm{mg} / \mathrm{l})\end{array}$ & $\begin{array}{c}\mathrm{Cu} \\
(\mathrm{ug} / \mathrm{l})\end{array}$ & $\begin{array}{c}\mathrm{Zn} \\
(\mathrm{ug} / \mathrm{l})\end{array}$ & $\begin{array}{c}\mathrm{Pb} \\
\text { (ug/l) }\end{array}$ & $\begin{array}{c}\mathrm{Cr} \\
\text { (ug/l) }\end{array}$ & $\begin{array}{l}\mathrm{Ni} \\
\text { (ug/l) }\end{array}$ \\
\hline & & & & & 1 & 2 & 3 & 4 & 5 & 6 & 7 & 8 & 9 & 10 & 11 & 12 & 13 & 14 & 15 \\
\hline \multirow[t]{3}{*}{ Fnjóská } & 1 & Ave & 6.08 & 3.43 & 7.57 & 52.64 & 4.50 & 0.02 & 0.01 & 0.21 & 0.01 & 1.45 & 4.00 & 5.45 & 0.61 & 2.00 & 0.03 & 1.13 & 0.26 \\
\hline & & $C_{\text {var }}$ & 0.80 & 0.93 & 0.02 & 0.10 & 0.71 & 0.43 & 0.32 & 0.21 & 0.23 & 0.24 & 0.26 & 0.25 & 1.46 & 0.20 & 0.99 & 0.25 & 1.10 \\
\hline & & Correl & 1,00 & 0.84 & 0.59 & -0.39 & -0.16 & -0.28 & -0.19 & -0.31 & -0.24 & 0.13 & 0.33 & 0.28 & 0.12 & -0.32 & 0.14 & 0.22 & 0.07 \\
\hline \multirow{3}{*}{$\begin{array}{l}\text { Skjalfanda } \\
\text { fljót }\end{array}$} & 2 & Ave & 5.58 & 4.16 & 7.55 & 97.70 & 13.17 & 0.03 & 0.02 & 0.23 & 0.01 & 1.84 & 7.12 & 8.96 & 1.58 & 2.83 & 0.05 & $1 ., 56$ & 0.76 \\
\hline & & $C_{\text {var }}$ & 0.91 & 1.00 & 0.03 & 0.12 & 1.59 & 0.38 & 0.33 & 0.46 & 0.81 & 0.14 & 0.23 & 0.19 & 1.57 & 0.58 & 1.20 & 0.76 & 1.39 \\
\hline & & Correl & 1.00 & 0.84 & 0.47 & -0.20 & 0.11 & -0.21 & -0.30 & -0.52 & -0.56 & -0.02 & -0.05 & -0.05 & 0.06 & 0.10 & 0.33 & 0.01 & 0.06 \\
\hline \multirow[t]{3}{*}{ Laxá } & 3 & Ave & 5.05 & 4.63 & 8.21 & 142.45 & 20.42 & 0.03 & 0.02 & 0.39 & 0.02 & 3.27 & 10.77 & 14.04 & 0.69 & 2.09 & 0.02 & 1.42 & 0.39 \\
\hline & & $C_{\text {var }}$ & 1.10 & 1.02 & 0.07 & 0.17 & 1.43 & 0.31 & 0.26 & 0.31 & 0.80 & 0.27 & 0.27 & 0.26 & 0.54 & 0.22 & 1.01 & 0.24 & 0.57 \\
\hline & & Correl & 1.00 & 0.85 & 0.65 & -0.15 & -0.06 & -0.55 & -0.15 & 0.37 & -0.54 & 0.58 & 0.15 & 0.26 & -0.32 & -0.09 & 0.13 & -0.32 & -0.21 \\
\hline \multirow[t]{3}{*}{ Ellidaár } & 4 & Ave & 6.73 & 6.45 & 8.46 & 90.42 & 12.67 & 0.01 & 0.01 & 0.10 & 0.01 & 1.68 & 4.16 & 5.83 & 0.45 & 0.84 & 0.03 & 0.96 & 0.27 \\
\hline & & $C_{\text {var }}$ & & & 0.09 & 0.05 & 1.08 & 0.37 & 0.10 & 0.38 & 0.59 & 0.30 & 0.10 & 0.13 & 0.41 & 0.49 & 0.61 & 0.16 & 0.26 \\
\hline & & Correl & 1.00 & 0.90 & 0.80 & -0.12 & 0.04 & -0.26 & 0.04 & 0.55 & 0.36 & 0.76 & 0.20 & 0.60 & -0.07 & -0.24 & 0.18 & -0.44 & -0.21 \\
\hline \multirow[t]{3}{*}{ Holmsá } & 5 & Ave & 6.09 & 5.16 & 8.12 & 88.08 & 36.67 & 0.01 & 0.01 & 0.10 & 0.01 & 1.28 & 4.11 & 5.39 & 0.32 & 0.77 & 0.02 & 0.98 & 0.29 \\
\hline & & $C_{\text {var }}$ & 1.15 & 0.90 & 0.05 & 0.07 & 1.50 & 0.40 & 0.22 & 0.48 & 0.39 & 0.17 & 0.11 & 0.09 & 0.56 & 0.59 & 0.68 & 0.11 & 0.39 \\
\hline & & Correl & 1.00 & 0.93 & 0.81 & -0.47 & 0.50 & -0.28 & -0.04 & -0.28 & -0.31 & 0.48 & 0.25 & 0.44 & -0.30 & -0.21 & -0.41 & -0.38 & -0.23 \\
\hline \multirow[t]{3}{*}{ Sudurá } & 6 & Ave & 6.01 & 5.02 & 8.12 & 90.17 & 18.00 & 0.01 & 0.01 & 0.44 & 0.01 & 1.13 & 3.65 & 4.78 & 0.41 & 0.87 & 0.02 & 0.95 & 0.31 \\
\hline & & $C_{\text {var }}$ & 1.24 & 0.72 & 0.05 & 0.06 & 2.27 & 0.36 & 0.19 & 2.67 & 0.26 & 0.24 & 0.30 & 0.26 & 0.25 & 0.52 & 0.66 & 0.12 & 0.45 \\
\hline & & Correl & 1.00 & 0.95 & 0.55 & -0.45 & 0.32 & -0.26 & -0.43 & 0.41 & -0.03 & -0.31 & -0.46 & -0.47 & 0.08 & -0.35 & -0.29 & -0.10 & 0.03 \\
\hline \multirow[t]{3}{*}{ Glerá } & 7 & Ave & 6.36 & 3.21 & 7.69 & 64.75 & 135.17 & 0.03 & 0.01 & 0.15 & 0.04 & 1.25 & 2.87 & 4.12 & 2.36 & 3.18 & 0.13 & 0.93 & 0.65 \\
\hline & & $c_{\text {var }}$ & 1.01 & & 0.04 & 0.31 & 1.50 & & 0.39 & 0.84 & 0.77 & 0.39 & 0.33 & 0.33 & 0.91 & 0.81 & 1.02 & 0.53 & 0.80 \\
\hline & & Correl & 1.00 & 0.82 & 0.29 & -0.27 & -0.06 & 0.27 & -0.25 & -0.25 & -0.23 & -0.16 & -0.09 & -0.12 & 0.43 & 0.33 & 0.38 & 0.30 & 0.41 \\
\hline \multirow{3}{*}{$\begin{array}{l}\text { Svarfaõar } \\
\text { dalsá }\end{array}$} & 8 & Ave & 4.71 & 3.12 & 7.51 & 61.75 & 103.83 & 0.03 & 0.00 & 0.23 & 0.01 & 1.49 & 3.41 & 4.90 & 1.73 & 3.38 & 0.09 & $0 ., 31$ & 0.62 \\
\hline & & & 1.07 & & 0.05 & & 2.61 & & & 0.8 & 0.57 & 0.3 & 0.22 & 0.2 & & & 0.9 & & 1.40 \\
\hline & & Correl & 1.00 & 0.64 & 0.50 & -0.21 & 0.28 & 0.33 & 0.03 & 0.30 & -0.66 & 0.38 & 0.06 & 0.23 & 0.39 & 0.14 & 0.22 & 0.37 & 0.13 \\
\hline \multirow[t]{3}{*}{ Hörgá } & 9 & Ave & 6.14 & 3.41 & 7.61 & 52.58 & 22.92 & 0.02 & 0.01 & 0.25 & 0.01 & 0.98 & 3.36 & 4.34 & 1.17 & 2.28 & 0.03 & 0.23 & 0.33 \\
\hline & & & 0.99 & 0.76 & 0.04 & 0.23 & 1.73 & 0.45 & 0.28 & 1.71 & 0.96 & 0.22 & 0.34 & 0.30 & & 0.7 & 0.64 & & 0.41 \\
\hline & & Correl & 1.00 & 0.65 & 0.33 & -0.46 & 0.20 & -0.06 & -0.43 & 0.34 & -0.23 & -0.13 & -0.45 & -0.41 & 0.23 & 0.29 & 0.00 & 0.07 & -0.20 \\
\hline \multirow{3}{*}{$\begin{array}{l}\text { Eyja } \\
\text { fjarðará }\end{array}$} & 10 & Ave & 6.40 & 4.38 & 7.57 & 65.45 & 37.75 & 0.02 & 0.01 & 0.14 & 0.01 & 1.51 & 3.65 & 5.16 & 1.28 & 1.47 & 0.02 & 0.50 & 0.30 \\
\hline & & & 1.05 & 0.74 & 0.03 & & 0.87 & & 0.29 & 0.52 & 0.85 & 0.25 & 0.28 & 0.23 & 1.13 & 0.67 & 0.78 & & 0.51 \\
\hline & & Correl & 1.00 & 0.74 & 0.59 & -0.14 & -0.11 & 0.01 & -0.57 & -0.18 & -0.75 & -0.27 & -0.18 & -0.24 & -0.23 & 0.08 & 0.22 & 0.20 & 0.05 \\
\hline \multirow[t]{3}{*}{ Botnsá } & 11 & Ave & 4.25 & 4.28 & 8.34 & 58.42 & 32.50 & 0.01 & 0.01 & 0.55 & 0.01 & 1.04 & 2.86 & 3.89 & 0.26 & 84.01 & 0.04 & 0.73 & 0.37 \\
\hline & & & 1.31 & & 0.10 & 0.11 & 1.58 & 0.32 & 0.17 & 2.99 & 0.41 & 0.44 & 0.35 & 0.33 & 0.49 & 2.57 & 0.87 & 0.48 & 0.57 \\
\hline & & Correl & 1.00 & 0.95 & 0.20 & -0.41 & 0.31 & 0.10 & 0.06 & -0.13 & -0.31 & -0.17 & 0.05 & -0.02 & -0.20 & 0.41 & -0.67 & 0.11 & 0.58 \\
\hline \multirow{3}{*}{$\begin{array}{l}\text { Brynju } \\
\text { dalsá }\end{array}$} & 12 & Ave & 4.33 & 4.28 & 7.97 & 54.42 & 9.42 & 0.01 & 0.01 & 0.09 & 0.01 & 0.94 & 2.58 & 3.51 & 0.65 & 44.48 & 0.07 & $0 ., 79$ & 0.40 \\
\hline & & & & 0.89 & 0.05 & & & 0.75 & 0.17 & 0.87 & 0.40 & 0.39 & 0.19 & 0.18 & 1.13 & 1.57 & 0.92 & 1.11 & 0.74 \\
\hline & & Correl & 1.00 & 0.98 & 0.06 & -0.62 & 0.55 & 0.05 & 0.14 & -0.02 & -0.49 & -0.43 & -0.44 & -0.62 & -0.22 & -0.33 & -0.36 & 0.09 & -0.19 \\
\hline \multirow[t]{3}{*}{ Fossá } & 13 & Ave & 4.50 & 4.10 & 7.76 & 59.00 & 2.50 & 0.01 & 0.01 & 0.08 & 0.01 & 0.99 & 2.71 & 3.69 & 0.31 & 98.42 & 0.04 & 0.57 & 0.32 \\
\hline & & & 1.28 & 0.97 & 0.04 & & 1.11 & 0.28 & 0.23 & 1.33 & 0.53 & 0.48 & 0.43 & 0.40 & 0.75 & 1.38 & 0.74 & 0.68 & 0.62 \\
\hline & & Correl & 1.00 & 0.97 & -0.22 & -0.50 & 0.42 & 0.33 & -0.01 & -0.31 & -0.13 & -0.14 & 0.25 & 0.15 & -0.15 & -0.21 & -0.43 & -0.42 & 0.01 \\
\hline \multirow[t]{3}{*}{ Kiōafellsá } & 14 & Ave & 4.75 & 4.48 & 7.79 & 92.83 & 30.42 & 0.02 & 0.01 & 0.35 & 0.01 & 1.94 & 5.56 & 7.34 & 0.58 & 157.78 & 0.04 & 0.67 & 0.71 \\
\hline & & & 1.19 & 0.83 & 0.02 & 0.18 & 1.91 & 0.25 & 0.40 & 1.47 & 0.84 & 0.45 & 0.36 & 0.34 & 0.78 & 1.62 & 0.42 & 0.55 & 0.49 \\
\hline & & & 1.00 & 0.97 & 0.06 & -0.24 & 0.11 & -0.39 & -0.18 & -0.12 & -0.24 & -0.08 & -0.14 & -0.14 & 0.15 & -0.09 & -0.39 & -0.42 & 0.12 \\
\hline
\end{tabular}

HESSD

4, 2561-2585, 2007

\section{Statistical}

\section{distribution of series}

\section{J. Eliasson and}

T. Thordarson

Title Page

\begin{tabular}{|c|c|}
\hline Abstract & Introduction \\
\hline Conclusions & References \\
\hline Tables & Figures \\
\hline I4 & \\
\hline & \\
\hline Back & \\
\hline Full Screen / Esc \\
\hline Printer-friendly Version \\
\hline Interactive Discussion
\end{tabular}




\section{HESSD}

4, 2561-2585, 2007

\section{Statistical \\ J. Eliasson and \\ T. Thordarson}

distribution of series

Title Page

Table 2. $K$ values for DoC.

\begin{tabular}{ccccccccccc}
\hline$P \%$ & 5 & 10 & 25 & 50 & 60 & 75 & 90 & 95 & 97.5 & 99 \\
$K$ & -1.25 & -0.96 & -0.64 & 0.27 & 0 & 0.51 & 1.48 & 2.17 & 2.65 & 2.93 \\
\hline
\end{tabular}

Abstract

Introduction

Conclusions

References

Tables

Figures

14

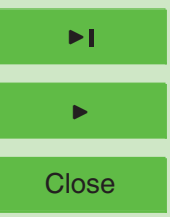

Back

Close

Full Screen / Esc

Printer-friendly Version

Interactive Discussion

EGU 


\section{HESSD}

4, 2561-2585, 2007

\section{Statistical \\ distribution of series}

J. Eliasson and

T. Thordarson

Table 3. Determined classes for the rivers in Table 1 by $90 \%$ values and averages $(60 \%)$.

\begin{tabular}{|c|c|c|c|c|c|c|c|c|c|c|c|c|c|c|c|c|c|c|c|c|c|c|c|}
\hline \multirow[b]{2}{*}{ Confidence level } & \multirow[t]{2}{*}{ Region } & \multicolumn{2}{|c|}{$\begin{array}{l}\text { Fec. colif. } \\
100 \mathrm{ml}\end{array}$} & \multicolumn{2}{|c|}{$\begin{array}{c}\mathrm{t}-\mathrm{P} \\
(\mathrm{mg} / \mathrm{l})\end{array}$} & \multicolumn{2}{|c|}{$\begin{array}{l}\text { PO4-P } \\
\text { (mg/l) }\end{array}$} & \multicolumn{2}{|c|}{$\begin{array}{c}\mathrm{t}-\mathrm{N} \\
(\mathrm{mg} / \mathrm{l})\end{array}$} & \multicolumn{2}{|c|}{$\begin{array}{l}\text { TOC } \\
(\mathrm{mg} / \mathrm{l})\end{array}$} & \multicolumn{2}{|c|}{$\begin{array}{c}\mathrm{Cu} \\
\text { (ug/l) }\end{array}$} & \multicolumn{2}{|c|}{$\begin{array}{c}\mathrm{Zn} \\
\text { (ug/l) }\end{array}$} & \multicolumn{2}{|c|}{$\begin{array}{l}\mathrm{Pb} \\
\text { (ug/l) }\end{array}$} & \multicolumn{2}{|c|}{$\begin{array}{c}\mathrm{Cr} \\
(\mathrm{ug} / \mathrm{l})\end{array}$} & \multicolumn{2}{|c|}{$\begin{array}{c}\mathrm{Ni} \\
(\mathrm{ug} / \mathrm{l})\end{array}$} & \multicolumn{2}{|c|}{$C_{\max }$} \\
\hline & & $90 \%$ & $60 \%$ & $90 \%$ & $60 \%$ & $90 \%$ & $60 \%$ & $90 \%$ & $60 \%$ & $90 \%$ & $60 \%$ & $90 \%$ & $60 \%$ & $90 \%$ & $60 \%$ & $90 \%$ & $60 \%$ & $90 \%$ & $60 \%$ & $90 \%$ & $60 \%$ & $90 \%$ & $60 \%$ \\
\hline Fnjóská & $\mathrm{N}$ & 1 & 2 & 2 & 1 & 3 & 2 & 2 & 1 & 2 & 2 & 2 & 2 & 1 & 1 & 1 & 1 & 2 & 2 & 1 & 1 & 3 & 2 \\
\hline Skjalfanda & $\mathrm{N}$ & 2 & 1 & 3 & 2 & 3 & 2 & 2 & 1 & 2 & 2 & 3 & 2 & 2 & 1 & 1 & 2 & 2 & 2 & 2 & 2 & 3 & 2 \\
\hline Laxá & $\mathrm{N}$ & 2 & 2 & 3 & 2 & 3 & 3 & 2 & 2 & 3 & 3 & 2 & 2 & 1 & 1 & 1 & 1 & 2 & 2 & 2 & 1 & 3 & 3 \\
\hline Ellidaa E1 & s & 2 & 1 & 1 & 1 & 2 & 1 & 1 & 1 & 2 & 2 & 2 & 2 & 1 & 1 & 1 & 1 & 2 & 2 & 1 & 1 & 2 & 2 \\
\hline Holmsá & $\mathrm{s}$ & 3 & 2 & 1 & 1 & 1 & 1 & 1 & 1 & 2 & 1 & 2 & 2 & 1 & 1 & 1 & 1 & 2 & 2 & 1 & 1 & 3 & 2 \\
\hline Sudurá & $\mathrm{s}$ & 2 & 2 & 1 & 1 & 2 & 1 & 4 & 1 & 2 & 1 & 2 & 2 & 1 & 1 & 1 & 1 & 2 & 2 & 1 & 1 & 4 & 2 \\
\hline Glerá & $\mathrm{N}$ & 4 & 3 & 3 & 2 & 2 & 1 & 2 & 1 & 2 & 1 & 3 & 2 & 2 & 1 & 2 & 1 & 2 & 2 & 2 & 1 & 4 & 2 \\
\hline Svarfaðardalsá & $\mathrm{N}$ & 4 & 3 & 3 & 2 & 2 & 1 & 2 & 1 & 2 & 1 & 3 & 2 & 2 & 1 & 2 & 1 & 2 & 2 & 2 & 1 & 4 & 3 \\
\hline Hörgá & $\mathrm{N}$ & 2 & 1 & 3 & 2 & 2 & 1 & 3 & 1 & 2 & 1 & 2 & 2 & 2 & 1 & 1 & 1 & 2 & 1 & 1 & 1 & 3 & 2 \\
\hline Eyjafjaròará & $\mathrm{N}$ & 2 & 2 & 2 & 1 & 2 & 1 & 1 & 1 & 2 & 2 & 3 & 2 & 1 & 1 & 1 & 1 & 2 & 2 & 1 & 1 & 3 & 2 \\
\hline Botnsá & s & 2 & 2 & 1 & 1 & 1 & 1 & 4 & 1 & 2 & 1 & 2 & 1 & 5 & 2 & 1 & 1 & 2 & 2 & 2 & 1 & 5 & 2 \\
\hline Brynjudalsá & s & 2 & 1 & 2 & 1 & 2 & 1 & 1 & 1 & 2 & 1 & 2 & 2 & 4 & 3 & 1 & 1 & 2 & 2 & 2 & 1 & 4 & 3 \\
\hline Fossá & $\mathrm{s}$ & 1 & 1 & 2 & 1 & 2 & 1 & 1 & 1 & 2 & 1 & 2 & 1 & 4 & 4 & 1 & 1 & 2 & 2 & 1 & 1 & 4 & 4 \\
\hline Kiōafellsá & s & 3 & 2 & 2 & 1 & 3 & 2 & 3 & 1 & 3 & 2 & 2 & 2 & 5 & 4 & 1 & 1 & 2 & 2 & 2 & 2 & 5 & 4 \\
\hline Mean & & & & & & & & & & & & & & & & & & & & & & 3.6 & 2.4 \\
\hline
\end{tabular}

Title Page

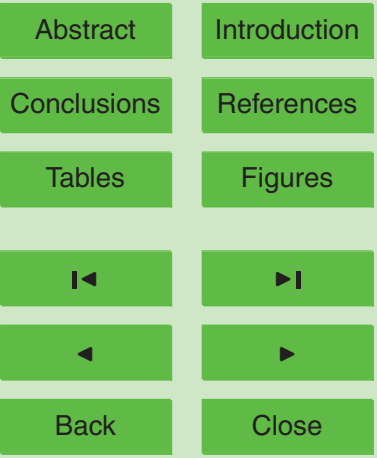

Full Screen / Esc

Printer-friendly Version

Interactive Discussion 


\section{HESSD}

4, 2561-2585, 2007

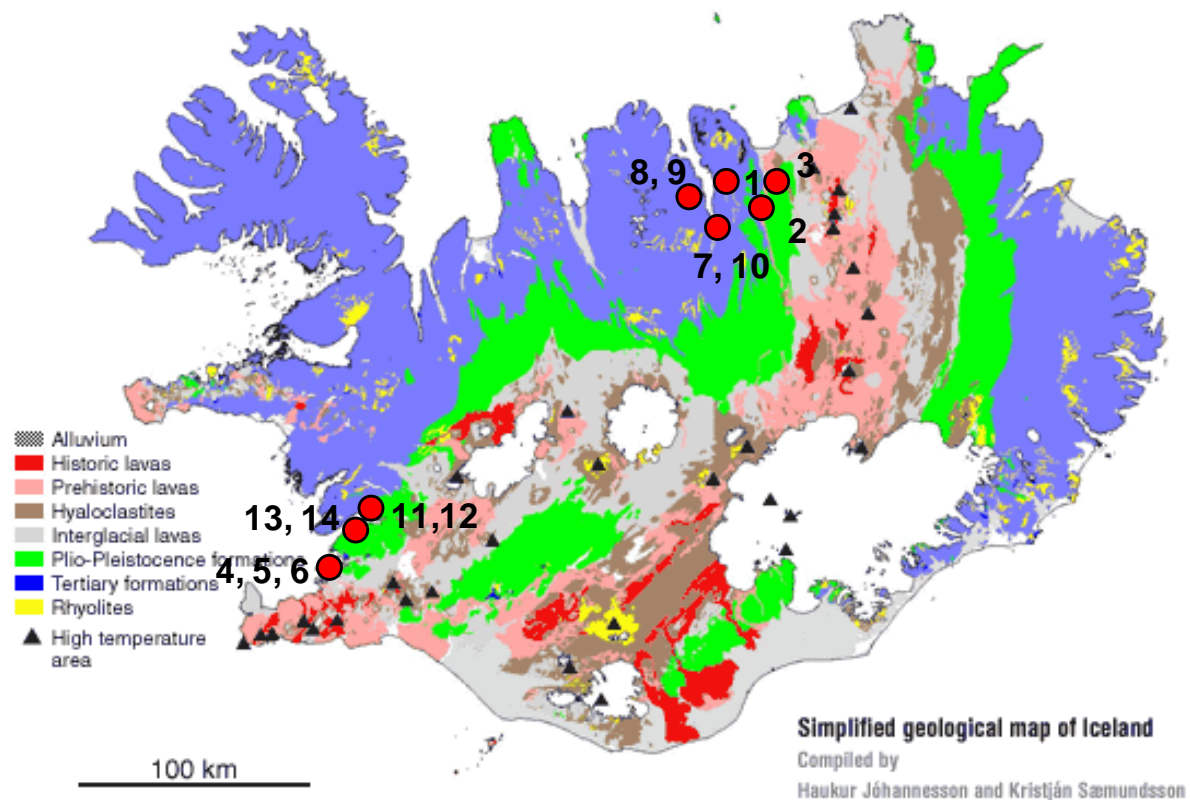

\section{Statistical}

distribution of series

J. Eliasson and

T. Thordarson

Title Page

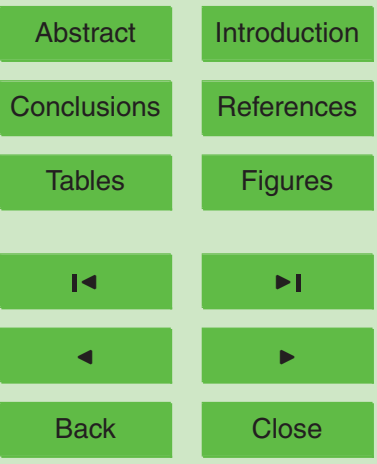

Full Screen / Esc

and 6 are in the capital area, the others in scarcely populated areas with some farming, cattle gassing and summer cabins in the catchments' area.

Printer-friendly Version

Interactive Discussion 


\section{HESSD}

4, 2561-2585, 2007

\section{Statistical \\ distribution of series}
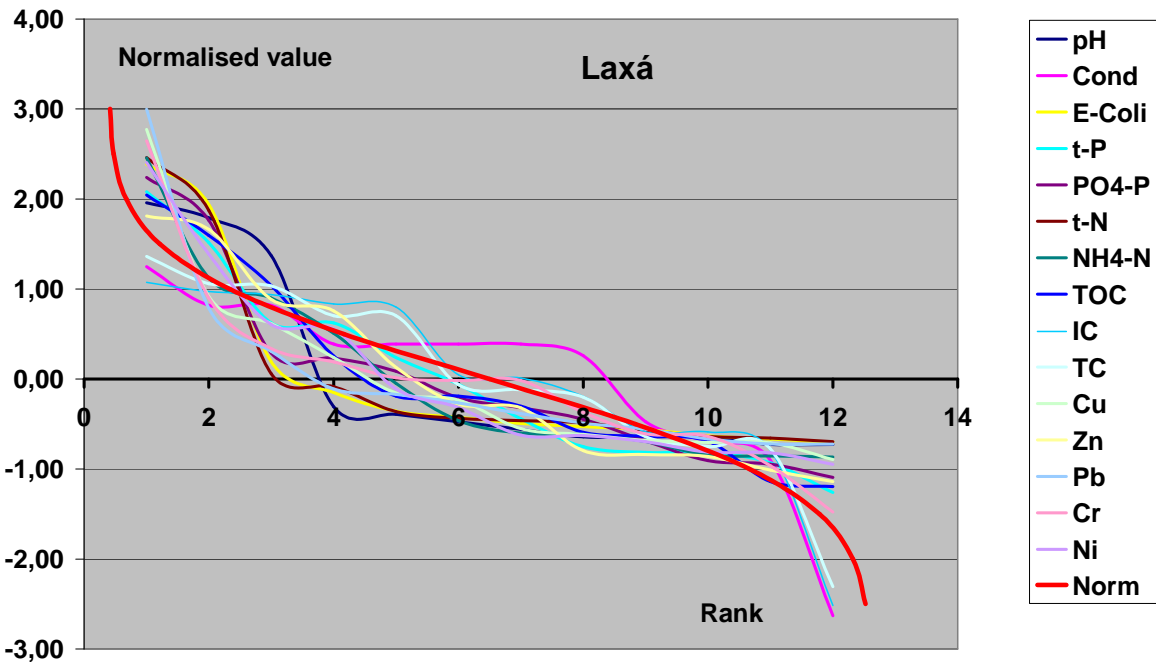

Fig. 2. Distributions of the ranked constituents in Laxa. The deviations of Conductivity and pH are unusually large. The thick line is the normal distribution
J. Eliasson and

T. Thordarson

\section{Title Page}

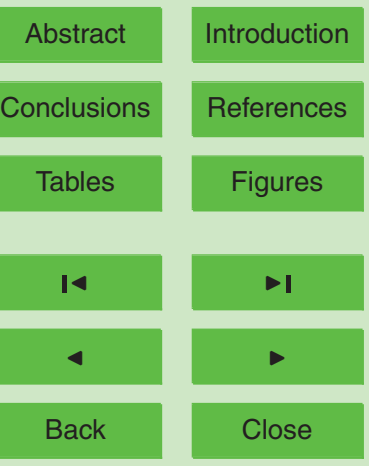

Full Screen / Esc

Printer-friendly Version

Interactive Discussion 


\section{HESSD}

4, 2561-2585, 2007
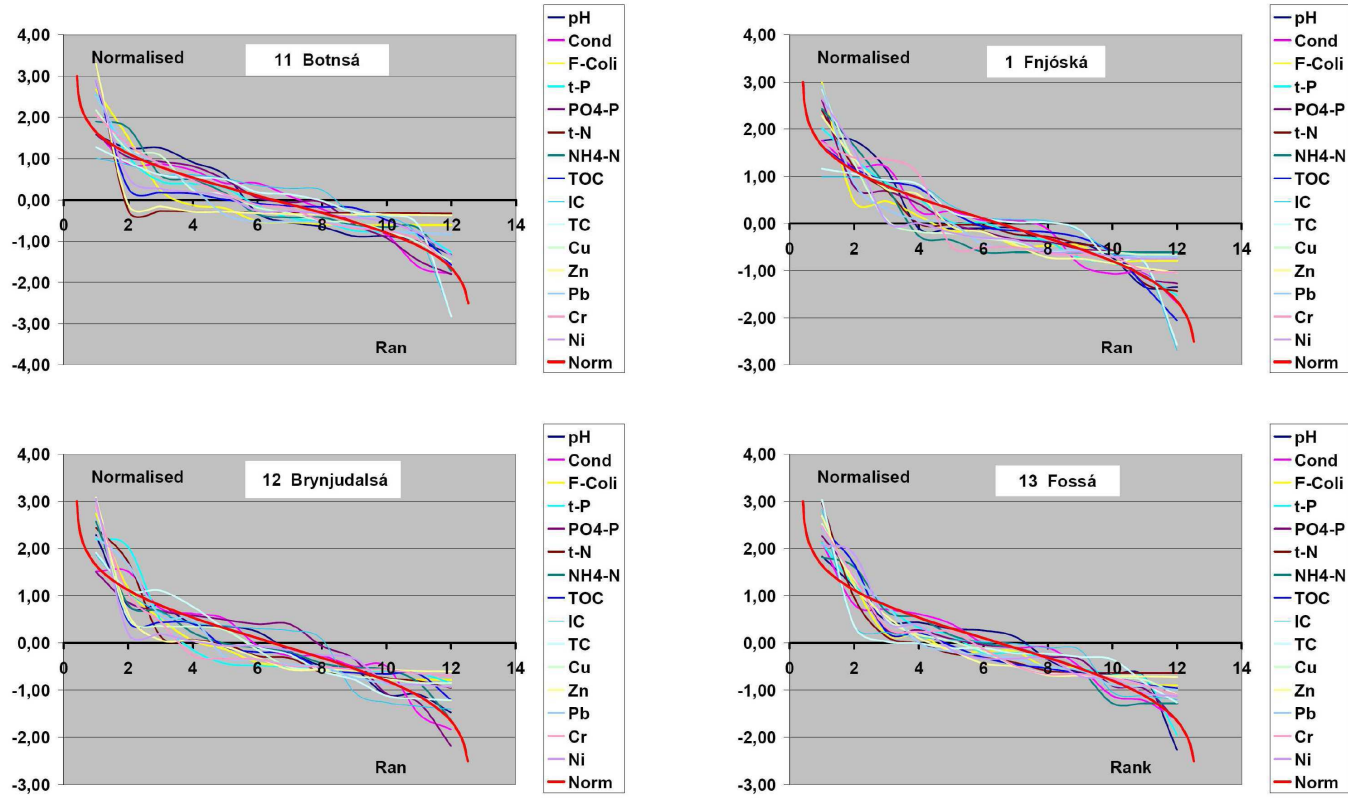

Fig. 3. Plots of the normalized constituents in 8 selected rivers compared to the normal distribution (red line). Note the rank (probability measure) is on the horizontal axis opposite to tradition in statistics. Each constituent has the same color in all 8 figures.

Title Page

\section{Statistical} distribution of series

J. Eliasson and

T. Thordarson

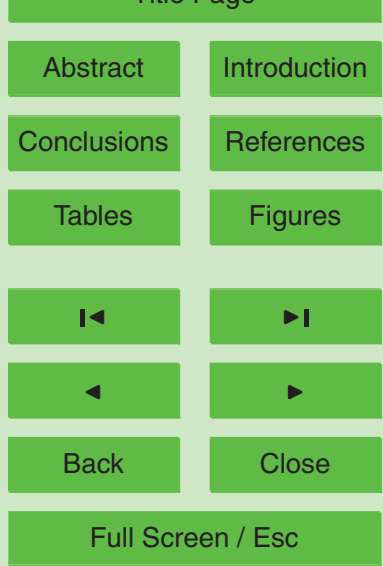

Printer-friendly Version

Interactive Discussion 
HESSD

4, 2561-2585, 2007

\section{Statistical \\ distribution of series}

J. Eliasson and

T. Thordarson

Title Page

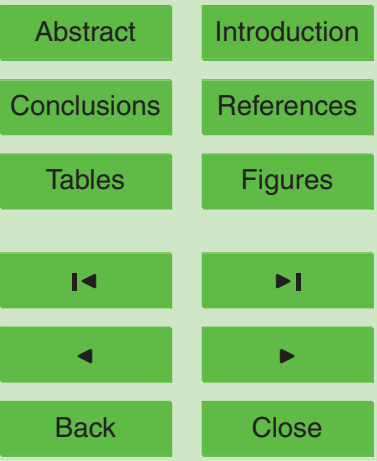

Full Screen / Esc

Printer-friendly Version

Interactive Discussion 


\section{HESSD}

4, 2561-2585, 2007

\section{Statistical \\ distribution of series}
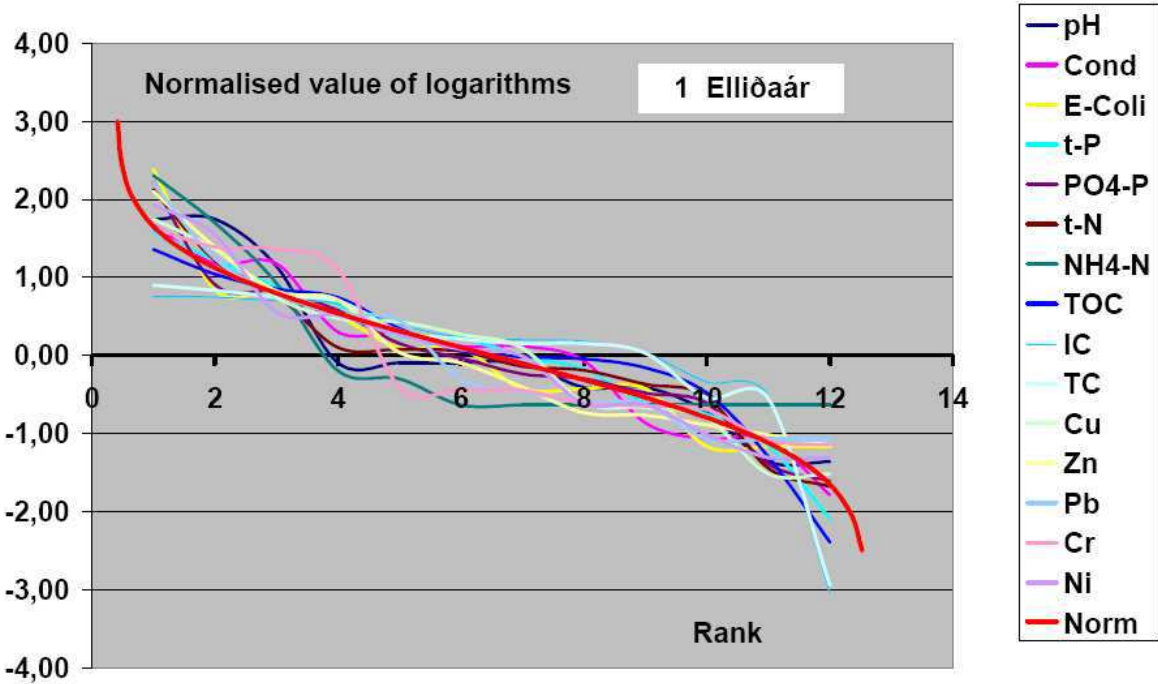

J. Eliasson and

T. Thordarson

Title Page

Abstract

Introduction

Conclusions

References

Tables

Figures

14

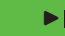

4

\section{Back}

Close

Full Screen / Esc bution (red line). Note that the rank (probability measure) is on the horizontal axis opposite to tradition in statistics.

Printer-friendly Version

Interactive Discussion 


\section{HESSD}

4, 2561-2585, 2007

\section{Statistical \\ distribution of series}

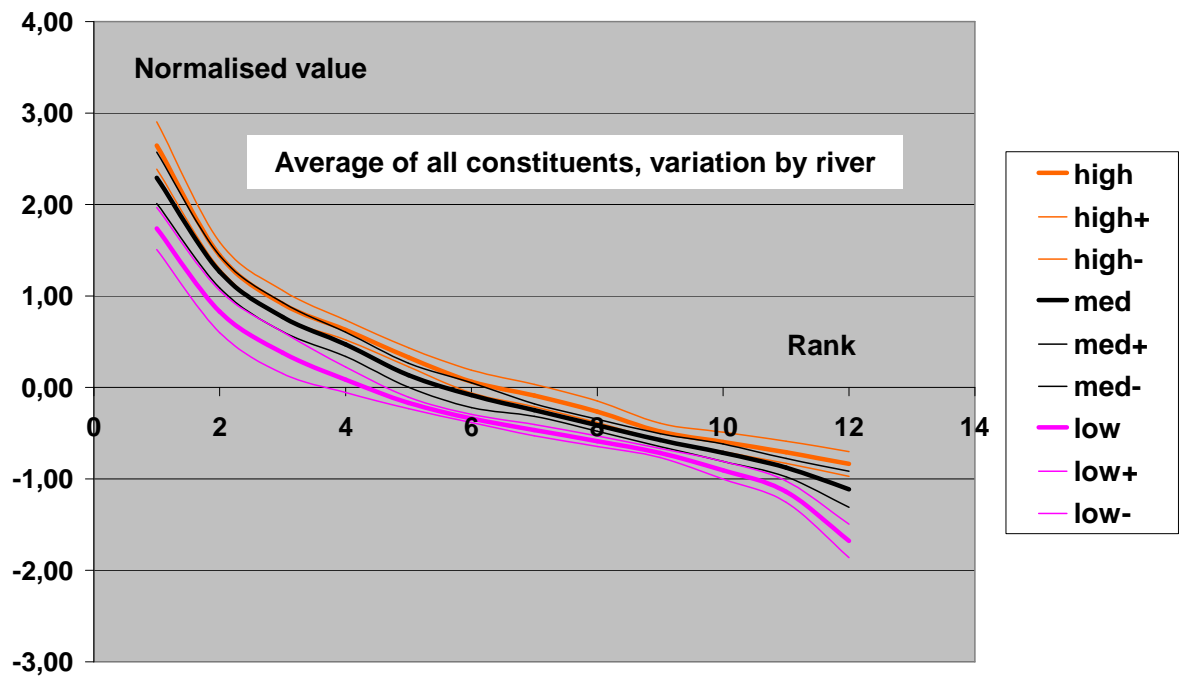

J. Eliasson and

T. Thordarson

\section{Title Page}

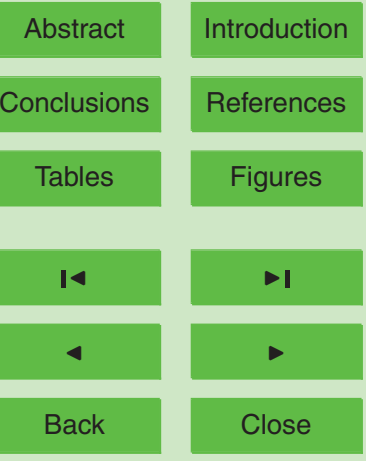

Full Screen / Esc

Printer-friendly Version

Interactive Discussion 


\section{HESSD}

4, 2561-2585, 2007

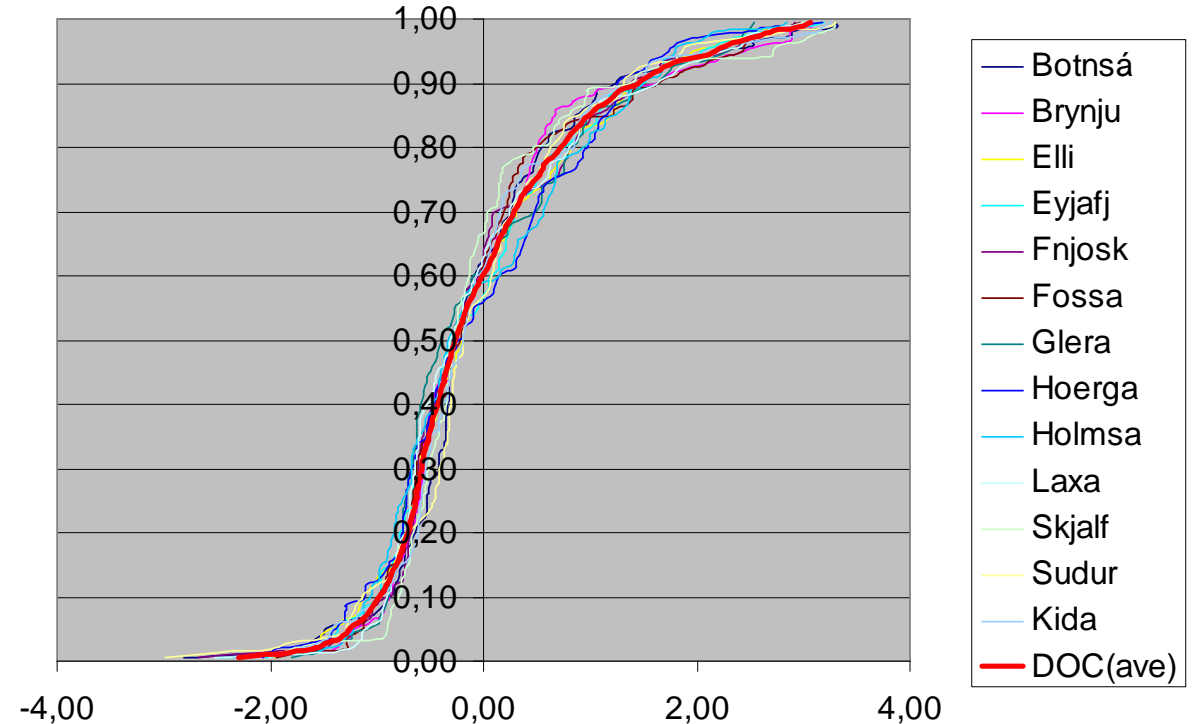

Fig. 6. Distribution of constituents (DoC) found as the average value of all the empirical distribution found by pooling each individual river.

\section{Statistical \\ distribution of series}

J. Eliasson and

T. Thordarson

Title Page

Abstract

Introduction

Conclusions

References

Tables

Figures

14

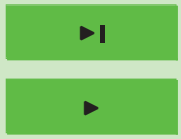

Back

Close

Printer-friendly Version

Interactive Discussion 


\section{HESSD}

4, 2561-2585, 2007

\section{Statistical \\ distribution of series}

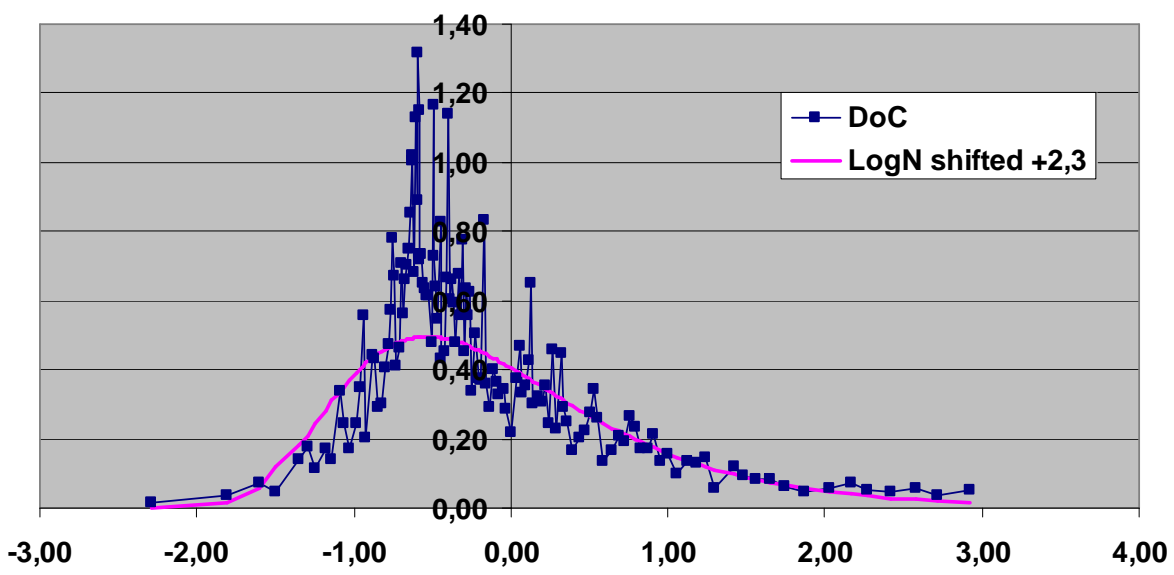

J. Eliasson and

T. Thordarson

Title Page

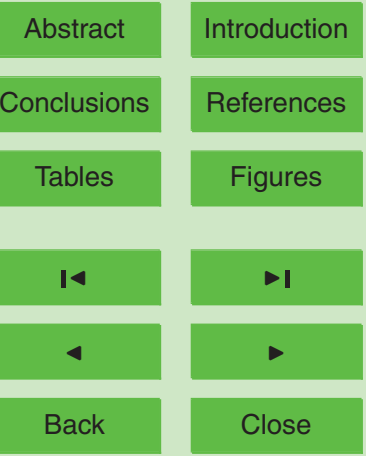

Full Screen / Esc

Printer-friendly Version

Interactive Discussion

EGU 